International Journal of Linguistics, Literature and Culture
Available online at https://sloap.org/journals/index.php/ijllc/
Vol. 6, No. 2, March 2020, pages: 12-20
ISSN: 2455-8028
https://doi.org/10.21744/ijllc.v6n2.864

\title{
Pentahelix Model Application for Tourism Development Strategy
}

\author{
Mangido Nainggolan a \\ I Wayan Ardika ${ }^{\text {b }}$ \\ I Ketut Ardhana ${ }^{c}$ \\ I Ketut Setiawan ${ }^{\text {d }}$
}

\section{Article history:}

Submitted: 09 December 2019

Revised: 18 January 2020

Accepted: 27 February 2020

\section{Keywords:}

Indonesia;

pentahelix;

stakeholders;

Toba Samosir;

tourism;

\begin{abstract}
This study discussed the application of the Pentahelix model in the development strategies of Toba Samosir tourism. The current research was conducted using a qualitative method with a phenomenological approach. It aimed at exploring how stakeholder synergy in each formulation, as well as the development of tourism. Research data were collected through observation, interviews, literature review, and surveys. The results showed that the lack of synergy between stakeholders caused the low number of tourist visits. The government tends to assume that the stakeholders are the sole owner of the power so that the development of tourism has not been able to produce welfare, even, it tends to cause prolonged conflict within the community itself. Therefore, the current study proposes a vital step of pentahelix model, in which the government of local regency should have better synergy with stakeholders.
\end{abstract}

International journal of linguistics, literature and culture () 2020. This is an open access article under the CC BY-NC-ND license (https://creativecommons.org/licenses/by-nc-nd/4.0/).

Corresponding author:

Mangido Nainggolan,

Doctoral Program of Cultural Studies, Universitas Udayana, Indonesia.

Email address: golanbatuara71@gmail.com

\footnotetext{
${ }^{a}$ Universitas Udayana, Denpasar, Indonesia

${ }^{\mathrm{b}}$ Universitas Udayana, Denpasar, Indonesia

${ }^{\text {c } U n i v e r s i t a s ~ U d a y a n a, ~ D e n p a s a r, ~ I n d o n e s i a ~}$

${ }^{\mathrm{d}}$ Universitas Udayana, Denpasar, Indonesia
} 


\section{Introduction}

The Government of the Republic of Indonesia places the tourism sector as the driving force of the Indonesian economy. It is a top priority besides infrastructure, maritime, energy, and food, for economic development in Indonesia. The Government of Indonesia has been targeting the tourism sector in 2019, which must be able to bring in 20 million foreign tourists as well as domestic tourists as much as 275 million people. In addition, the tourism sector in 2019 was targeted to be able to contribute to the national Gross Domestic Product (GDP) of $15 \%$ with the foreign exchange as much as IDR 260 trillion. Furthermore, the tourism sector must be able to create jobs of 12.6 million people, and the competitiveness index has to reach $30^{\text {th }}$ rank in the world.

To realize these targets, stakeholders from the central and regional levels must work hard, which is to make various strategic innovations. According to Sedarmayanti (2014), tourism development must be carried out based on four criteria, namely 1) be based on the results of deliberations and consensus of all stakeholders, 2) must provide benefits to the people, 3) based on the principle of healthy environment and ecology, as well as not contrary to social values, culture, and religious traditions of the local population, and; 4) do not place the community in a marginalized position. Therefore, the success of the implementation of tourism development can be achieved and meet the integration and synergy between the government, academics, the community, the media, and the tourism industry. The integration is called Pentahelix.

The Pentahelix model was first launched by former tourism minister of Indonesia, as issued in the Republic of Indonesia Ministerial Regulation Number 14 of 2016 concerning Guidelines for Sustainable Tourism Destinations. Pentahelix model is one of the references to develop synergy between related agencies in order to be optimal in order to achieve the goals of tourism development.

Next, the current study was held in Toba Samosir Regency, Indonesia. The regency is included in one of the districts around the Lake Toba Area (LTA), which has been determined by the government to be one of the priority tourism destinations that are often referred to as the second Bali of Indonesia. Nevertheless, in the last five years, the number of tourist visits has remained low and even tends to continue to decline.

Table 1

Data of tourist visits to Toba Samosir Regency

\begin{tabular}{llll}
\hline No & Year & Number of visits & Note \\
\hline 1 & 1995 & 305.000 & High \\
2 & 2010 & 131.813 & Decreased \\
3 & 2011 & 123.004 & Decreased \\
4 & 2012 & 131.813 & Increased \\
5 & 2013 & 104.175 & Decreased \\
6 & 2014 & 116.088 & Increased \\
7 & 2015 & 114.594 & Decreased \\
\hline
\end{tabular}

Source: Statistic Office of Toba Samosir Regency, 2016

The real condition of tourist visits, which tends to decrease as in the table above, becomes a problem for the condition of tourism development in Toba Samosir Regency. The following data was taken from the Culture and Tourism Office of Toba Samosir Regency- Indonesia, which has been stated in the Toba Samosir Regency Profile book. It is seen that many potential tourism objects have been developed as tourist villages, namely:

a. Nature Tourism Region:

1. Lumban Silintong Beach, Janji Maria, Meat Tarabunga, and Ajibata Long Beach.

2. Dolok Tolong natural sightseeing, Senyum hill, Motung Ajibata, and Gurgur Tampahan.

3. Taman Eden Natural Tourism

4. Basiha Stone Sibodiala Village

b. Cultural / religious tourism areas:

1. Sisingamangaraja Grave Complex XII

2. Missionary Tomb of Dr. IL. Nomensen

Nainggolan, M., Ardika, I. W., Ardhana, I. K., \& Setiawan, I. K. (2020). Pentahelix model application for tourism development strategy. International Journal of Linguistics, Literature and Culture, 6(2), 12-18.

https://doi.org/10.21744/ijllc.v6n2.864 
3. Parmalim Village

4. D.I Panjaitan Park Monument complex

\section{c. Particular interest tourism area of Asahan river rafting}

Next, it is believed that the success of the tourism village management, in influencing the perception of tourists coming, is mostly determined by the quality of the promotional strategies undertaken by the developers in the area. Besides that, the promotional must be conducted through cooperation between government and stakeholders, as well as local people, which is called Pentahelix. Therefore, this study was conducted to examine more about tourism development in Indonesia, especially in LTA.

\section{Materials and Methods}

This study used a qualitative method with a phenomenological approach. It aimed at analyzing the pattern of social life sustainability of the community, by developing three premises, namely (1) humans act on something based on how they give meaning to something for them, (2) that the meaning comes from social interaction with others and, (3) the meaning is refined when the process of social interaction takes place (Blumer, 1969; Poloma, 1984).

Qualitative research with a phenomenological approach explains how individuals see, describe, and interpret the social world (Suyanto, 2015). Through qualitative research, data can be collected and analyzed to answer problems related to the application of the pentahelix model in tourism development of Toba Samosir Regency, North SumatraIndonesia.

This research was conducted in the tourist destination of Toba Samosir Regency, carried out starting from May to November 2018. Next, the discussion of the research was carried out by comparing the previous studies which correlate with the problem being studied, namely (1) research conducted by Siregar et al. (2018), about the development of Lake Toba tourism area at Toba Samosir Regency. It analyzed the development of tourist attractions that include issues of accessibility, infrastructure and facilities, social conditions, and community support. The results show that the aspects of accessibility and community support have a lower category than other aspects. The aspect that needs to be prioritized in the development of the Lake Toba tourism area is the accessibility aspect. Related to this, efforts are needed to provide and improve accessibility conditions for the development of the Lake Toba tourism area in Toba Samosir Regency.

Next, (2) research conducted by Nurmalia (2018), about development strategy with the Pentahelix model, in Padurenan village- Indonesia. The results showed that there are five stakeholders involved in supporting the successful development of the SME embroidery and confection of Padurenan village. The strategy implemented by the government in collaboration with other stakeholders has been conducted well and produced satisfying results. Furthermore, in this study, data collection was carried out utilizing observation, interviews, literature, and surveys. The steps of data analysis, to produce the expected research discussion, are as follows: (1) Obtain data on the number of tourist visits in Toba Samosir district (2) Formulate stakeholder participation in the formulation and development of tourism in Toba Samosir district with the support of public opinion based on facts that happened; then (3) providing scientific recommendations to improve tourism development in Toba Samosir district.

\section{Results and Discussions}

In the ten tourism ministry priority programs of 2017, there are programs related to Human Resources (HR) capabilities, namely HR Competency Certification and Tourism Awareness Movement. With consideration to accelerate the development of Tourism Areas, and to unite the implementation of the authority to manage the area, Indonesian President, Jokowi, has signed Presidential Regulation No. 49 of 2016, concerning the Lake Toba Regional Management Authority Agency, which has direct responsibility to the President. In realizing the program, the collaboration between stakeholders is needed. The inter-field collaboration is formulated in the Pentahelix model, namely; 
Government

The role of the government in the development of tourism in Indonesia is crucial. As a regulator, facilitator as well as an operator of development, the government must be able to construct policies and regulations that guide all parties in the development of tourism following the specific characteristics of tourism in one region. Based on Article 5 and Article 23 paragraph 1D of the Tourism Law of Indonesia, the government and regional governments have several roles that are explicitly and implicitly explained. The roles are obliged to ensure that tourism is carried out based on principles that uphold religious norms and cultural values, includes (1) uphold human rights, diversity and local wisdom, (2) provide benefits for people's welfare, justice, equality, and proportionality, (3) preserve nature and the environment, (4) empower local communities, (5) ensure integration between sectors, between regions and between centers and regions, (6) adhere to the code of ethics of world tourism, as well as (7) strengthening the integrity of the Unitary Republic of Indonesia. Furthermore, in Article 23, paragraph 1D, the Government and Regional Government are obliged to supervise and control tourism activities that harm the lives of the wider community.

The Regional Government, as the primary holder of Toba Samosir tourism development, in its policy, seems not optimal. Tourism development without law enforcement following local wisdom values will cause prolonged conflict between the community and the government. This phenomenon has occurred in the tourism industry area of Toba Samosir district, specifically in the tourist destination of Lumban Bulbul, so that even though many tourists have visited this destination, it has actually not been able to contribute to the local government and even tends to fall into a prolonged conflict between the government and local community. The management tends to be unprofessional because it does not utilize the values of local wisdom. When a community's local wisdom is maintained, its culture must be maintained. If their culture is maintained, their uniqueness is also maintained. The uniqueness itself is essentially a tourist attraction (Basuki, 2016).

The policies implemented tend to be conducted without strategic formulation. It has caused prolonged conflict between the community and the government itself. The various programs implemented tend to be project-oriented so that the sustainability of development and supporting elements of tourism progress are often neglected. Furthermore, the values of local wisdom of the local community are almost not functioned. The government, which is supposed to be the protector, instructor, and companion for the community, is trapped in a hedonist ideology. The government is only concerned with the material rather than morality in the cultural context. The lack of involvement and empowerment of the local community indicates that the government tends to position itself as the sole authority in every policy that is programmed. The community is always placed in a hegemony position and becomes a victim of the hegemony. Marx put the state in a historical context and pulled it into a materialist conception of history, that is, the society, as well as its cultural forms the state (Gramsci, 2009).

Strozier \& Offer (2013), state that the leading group must offer a kind of economic corporation. It is needed since, undeniable, hegemony is sometimes an ethical-political. Marx further states that in terms of economic determinism, the economic sector is crucial (Ritzer, 2014). The hegemony practice strategy played by the government, in the context of tourism development, tends to be only as a political strategy of masking tourism. Thus, this has led to prolonged conflicts and social conflicts that disrupt the process of tourism development in the LTA.

\section{Academics}

The role of academics in the development of tourism has become very strategic. Through various scientific studies and analysis related to tourism marketing problems, and how the opportunities for developing a tourist attraction, academics role has been a vital strategy. It can be ensured that the tourists have a variety of motivations in each visit to each region with the diversity of the cultural community.

The academics people also play an essential role in providing views and analysis based on accurate data and theories following field conditions regarding the level of development and strategic formulas for advancing the development of tourism in one region. The role of the academic world is very influential in the development of the world of tourism. In other countries, the role of academics has been tremendously advanced for tourism. In the management and development of tourism, coordination and collaboration between stakeholders are needed. This concept has been programmed. Therefore, the academic is needed to be involved in the problem. Unfortunately, in Indonesia, it has never been realized optimally.

The tourism potential in Toba Samosir Regency is very tempting because it is supported by the availability of marine tourism objects such as beaches, mountain tourism, cultural tourism, and special interests. The potential is

Nainggolan, M., Ardika, I. W., Ardhana, I. K., \& Setiawan, I. K. (2020). Pentahelix model application for tourism development strategy. International Journal of Linguistics, Literature and Culture, 6(2), 12-18. https://doi.org/10.21744/ijllc.v6n2.864 
increasingly complemented by the seriousness of the central government in preparing supporting facilities such as the Toll Road, and the construction of the International Airport Silangit, which will undoubtedly make it easier for tourists to visit the LTA.

Furthermore, the involvement of academics is expected to be able to prepare skilled workers in the field of tourism, especially in the matter of hospitality, in order to spur an increase in the level of the community's economy. According to Pitana (2009), there are many positive impacts of tourism on the economy, including income from exchanging foreign money, improving the balance of foreign trade, income from tourism businesses or businesses, government revenue, income absorption of labor, and utilization of tourism facilities by local communities, which are impacted mostly by academics people.

\section{Tourism Industry}

Related to the term of the tourism industry, the notion of the industry itself is the quality of working hard, the production of goods, the creation of wealth by human efforts (Hornby et al., 2008). Industrial activities require hard work to succeed and can produce some products to provide satisfaction and well-being to humans. The product is a series of services that have economic, social, and psychological value. The services are a series of interrelated with each other and are unit called "package" (Hamalik, 1978). Tourism products consist of two types of complementarity, aspects relating to the products of other entrepreneurs, and aspects relating to factors of natural authenticity and human behavior. All of them are interdependent and must not be ugly because they can also cause ugliness in other aspects (Prajogo et al., 1995).

Tourism products have their characteristics that are different from other industrial products, namely, (1) It cannot be moved. Tourists come by themselves to enjoy and experience the product; (2) Products and consumption occur at the same time. It means that the product occurs at the time the subscription is using the services; (3) There is no objectively specified standard because tourism services come in various forms; (4) Subscribers cannot taste or know the product beforehand, except only seeing pictures with an explanation; (5) Tourism products are businesses that carry considerable risk and elastic. If there is a change in the economic situation, politics, declining community attitudes, it can shake the joints of investment in tourism businesses. Furthermore, the occurrence of massive setbacks will also affect the industry supporting tourism (Hornby et al., 2008).

The tourism industry is a process of economic activity in the field of tourism whose products are services to meet the needs of tourists in a comfortable (pleasant), privacy (it is not disturbed), and security (guaranteed personal security) so that tourists will feel that they are at home (Projogo, 2006; Brata \& Pemayun, 2018). The branches of the tourism industry, according to Hamalik (1978), consist of three types of facilities, namely (1) Main Tourism Supra Structure, that consists of travel agencies, tourist transportation, accommodation/ hotels, catering trade, tourist objects, souvenirs, etc. (2) Supplementing Tourism Supra Structure, including swimming pool, tennis court, golf court, recreation center, etc. (3) Supporting Tourism Supra Structure, namely night club, steam bath, and casino, etc.

\section{Society}

The form of community participation is also related to the political will of the authorities to provide opportunities for the community to participate in any tourism development effort. The growth and development of community participation indicate the recognition of government officials that the community is not merely an object or connoisseur of the results of development. They also become the subject or actors of development who have the ability and willingness to start from the planning, implementation, supervision, and utilization of the results of tourism development. The goal is that people avoid poverty and tourism development is indeed a source of welfare for the surrounding community.

Conceptually, the basic principle of community-based tourism is to place the community as the main actor through community empowerment in various tourism activities, so that the maximum benefit of tourism is for the community. The main target of tourism development must be to improve people's welfare. Designers of tourism development commonly use the concept of Community-Based Tourism (CBT). Strategies to mobilize the community to participate in the development as a tourism industry partner actively.

Based on the results of interviews with community leaders Lumban Bulbul, Mr. Lambok Simangunsong stated:

If the king (government) comes, then we (the people) are also king. Therefore their attitudes and behavior must be honored. We should not be treated as they like. The community should not be divided. We support the 
government's program in promoting tourism, but we must be included in its formulation so that we know what we want to make it following our customs so that we are happy, and we also feel valued.

The lack of involvement of community groups in efforts to formulate and develop tourism of Toba Samosir resulted in the emergence of prolonged conflict between fellow citizens with the authorities and business people. The political practices of the divide et empire, which are often played by the government, tend to color the community groups, which result in the passion for tourism development. It is always in a stagnant position. Community groups are often positioned only as objects that must be deceived and feared by masking the existing rules and regulations. CBT development requires coordination and cooperation, as well as a balanced role among all stakeholders. The basic principle of CBT must place the community as the main actor through empowerment in various tourism activities. The concept of CBT mobilizes communities to participate in any tourism development actively.

\title{
Media
}

The media acts as an institution that expands a program. It has an essential role in supporting publicity in the promotion and creating a brand image of a program for the public to know (Fanggidae, 2019; Suniastha Amerta, 2017). The existence of the media intersects directly with political and social struggles as well as helps to sustain the lives of people. Furthermore, it influences the way people think and act, the way they see themselves, and the way they build identity. It is closely related to power. The media also shape our views of the world, public opinion, values , and attitudes, and therefore an essential forum for the struggle for social power (Kellner, 2003).

Following Indonesian Law No. 40 of 1999, concerning press, it is stated that the press is a social institution and vehicle for mass communication that carries out journalistic activities that seek, obtain, possess, store, process, and deliver information in the form of text, sound, images, and data as well as graphics using print media, electronic media, and all types of television channels. The media, as a watchdog, give signals, early signs, opinions, and lead the future agenda. In Indonesian Law, article 3 No.40 of 1999 concerning press, it is stated that the function of the press is as an information media, educational media, source of entertainment, social control tools, and as an economic institution.

Related to the current research, data is presented as it was uttered by a resource who works as a regional journalist in the LTA. The following is the result of the interview.

\begin{abstract}
... as a journalist who has the duty and responsibility in terms of reporting and publication, the press should be an essential element that must be embraced in every element of tourism. The fact is that there has not been any collaboration carried out by the tourism ministry or the Regency Government of LTA towards journalists. There is no maximum effort of the press in reporting or promoting tourism. What is written by a journalist will influence readers' thinking related to the progress of tourism in the LTA (Interview with Ramsiana Gultom, Waspada Daily).
\end{abstract}

Following the information from the informant, it can be concluded that in the development efforts of Toba Samosir tourism, the role of the Media is not yet maximized. Journalists have never been invited or involved in any policy and formulation of tourism development. Whereas in order to support the success of tourism development, the aspect of promotion becomes something fundamental. It is more appropriate to be played by the media, both print, and electronic media. On the other side, the social media sites, through the Android system, also become one of the tools for the promotion (brand image) of tourism destinations (Nurdiyansah, 2014).

Finally, empowerment, in essence, is to prepare community groups so that they are able and willing to participate in any development programs actively. The growth and development of the participation of each stakeholder in the development process require trust and opportunity given by the government to the community. The government, as the regulator as well as a facilitator of tourism development, must realize that power always exists in every community, even though there is always power that cannot be shared equally among all members of the community. Power is found in all aspects of life. Power includes the ability to govern as well as to make decisions (Efriza, 2016).

Nainggolan, M., Ardika, I. W., Ardhana, I. K., \& Setiawan, I. K. (2020). Pentahelix model application for tourism development strategy. International Journal of Linguistics, Literature and Culture, 6(2), 12-18. https://doi.org/10.21744/ijllc.v6n2.864 


\section{Conclusion}

The development of tourism in LTA is still stagnant. The seriousness of the central government, in developing tourism in LTA, by pouring trillions of IDR, has not responded by the local government correctly and adequately. These facts can be seen in the following table.

Table 2

Toba Samosir Regency Business Field 2015

\begin{tabular}{lll}
\hline No & Type of business & Value of income (\%) \\
\hline 1 & Agriculture, Forestry and Animal Husbandry & 34.99 \\
2 & Wholesale and retail trade, Car and motorcycle repair & 13.85 \\
3 & Construction & 12.98 \\
4 & Provision of accommodation and food and drink & 12.01 \\
5 & Electricity and gas supply & 9.84 \\
6 & Transportation and trade & 3.09 \\
7 & Processing industry & 2.88 \\
8 & Transportation and trade & 2.78 \\
9 & Educational Services & 2.57 \\
10 & Water supply, waste management, waste, and recycling & 1.57 \\
11 & Government administration, defense, and mandatory social security & 1.06 \\
12 & Company services & 0.84 \\
13 & Health services and social activities & 0.15 \\
14 & Other services & 0.9 \\
\hline
\end{tabular}

Based on an analysis of the GRDP development mentioned above, it can be concluded that regional income from the tourism sector has not shown any maximum results. The government, following the power they have, does not seem to realize that they are not the sole owner of that power. The power they have must be utilized to empower the community, not to deceive the community. Furthermore, the district government must be able to build people's participation by implementing the pentahelix model, which has proven successful in realizing development success.

The proper application of the Pentahelix model is one of the tangible proofs that the regional government can work together with every existing institution so that each field can participate in every effort to implement the tourism development program. This will be a solution of a prolonged conflict in the life of the nation and state community. Moreover, the tourism development efforts of Toba Samosir regency will succeed optimally following what has been programmed by the central government of Indonesia, which is to make the LTA as a worldly tourist destination.

\section{Conflict of interest statement}

The authors declared that they have no competing interests.

\section{Statement of authorship}

The authors have a responsibility for the conception and design of the study. The authors have approved the final article.

\section{Acknowledgments}

We are grateful to two anonymous reviewers for their valuable comments on the earlier version of this paper. 


\section{References}

Basuki, A. (2016). Kebijakan pembangunan kepariwisataan. Malang: Intrans Publishing.

Blumer, H. (1969). Symbolic interactionism: Perspective and method. Berkeley.

Brata, I. B., \& Pemayun, A. G. P. (2018). Human Resource Competency Tourism Bali together with ASEAN Economic Community. International Research Journal of Management, IT and Social Sciences, 5(2), $186-194$.

Efriza, K. P. (2016). Perkembangan Konsep. Analisis dan Kritik, Malang: Intrans Publishing.

Fanggidae, J. P. (2019). Relationships between advertising value and dimensions of advertising. The International Journal of Social Sciences World (TIJOSSW), 1(01), 48-57.

Gramsci, A. (2009). Literatura y vida nacional. Las cuarenta.

Hamalik, O. (1978). Travel \& Tour Asas-Metode-Teknik.

Hornby, G., Brunetto, Y., \& Jennings, G. (2008). The Role of Inter-Organizational Relationships in Tourism Operators' Participation in Destination Marketing Systems. Journal of Hospitality \& Leisure Marketing, 17(1-2), 184-215. https://doi.org/10.1080/10507050801978448

Kellner, D. (2003). Media culture: Cultural studies, identity and politics between the modern and the post-modern. Routledge.

Nurdiyansah (2014). Peluang dan Tantangan Pariwisata Indonesia. Bandung Alfabeta.

Nurmalia (2018). Strategi Pengembangan Usaha Mikro, Kecil, dan Menengah (Umkm) dengan Model Penta Helix (Studi pada UMKM Sentra Bordir dan Konfeksi Desa Padurenan Kecamatan Gebog Kabupaten Kudus).

Pitana, I. Gde dan I Ketut Surya Diarta. 2009. Pengantar Ilmu Pariwisata.

Poloma, M. M. (1984). Contemporary Sociology: A. Contemporary Sociology, 42, 3.

Prajogo, D. I. (2006). The relationship between innovation and business performance-a comparative study between manufacturing and service firms. Knowledge and process management, 13(3), 218-225. https://doi.org/10.1002/kpm.259

Prajogo, T., Al-Bender, F., \& Van Brussel, H. (1995). Identification of pre-rolling friction dynamics of rolling element bearings: modelling and application to precise positioning systems. In Proceedings of the 8th International Precision Engineering Seminar (pp. 229-232).

Ritzer, G. (2014). The "Sharing" Economy, Uber, and the Triumph of Neo-Liberalism. George Ritzer, available at: https://georgeritzer. wordpress. com/2014/11/05/the-sharingeconomy-uber-and-the-triumph-of-neoliberalism.(accessed April 4, 2015).

Sedarmayanti, H. J. (2014). Manajemen Sumber Daya Manusia, Reformasi Birokrasi, Dan Manajemen Negeri Sipil. Seventh Printing. Bandung: Refika Aditama.

Siregar, D., Nurdiyanto, H., Sriadhi, S., Suita, D., Khair, U., Rahim, R., ... \& Siahaan, A. P. U. (2018, June). MultiAttribute Decision Making with VIKOR Method for Any Purpose Decision. In Journal of Physics: Conference Series (Vol. 1019, No. 1, p. 012034). IOP Publishing.

Strozier, C. B., \& Offer, D. (Eds.). (2013). The leader: Psychohistorical essays. Springer Science \& Business Media.

Suniastha Amerta, I. M. (2017). The role of tourism stakeholders at Jasri tourism village development, Karangasem regency. International Journal of Social Sciences and Humanities, 1(2), $20-28$. https://doi.org/10.29332/ijssh.v1n2.32

Suyanto, B. (2015). Metode Penelitian Sosial: Berbagai Alternatif Pendekatan. Prenada Media.

Nainggolan, M., Ardika, I. W., Ardhana, I. K., \& Setiawan, I. K. (2020). Pentahelix model application for tourism development strategy. International Journal of Linguistics, Literature and Culture, 6(2), 12-18. 


\section{Biography of Authors}

\begin{tabular}{|c|c|}
\hline & $\begin{array}{l}\text { Mangido Nainggolan is a candidate Doctor of Cultural Study Program at Universitas } \\
\text { Udayana, Denpasar, Indonesia. } \\
\text { Email: golanbatuara71@gmail.com }\end{array}$ \\
\hline & $\begin{array}{l}\text { Prof. Dr. I Wayan Ardika. M.A. Is a professor in Archeologi Department at Universitas } \\
\text { Udayana, Denpasar, Indonesia. He received his Master in prehistory from Australian } \\
\text { National University in } 1987 \text { and hid Doktorate in Prehistory at Austrdlian National } \\
\text { University in 1992. His research interests include a wide range of topics related to } \\
\text { Archeologi and Cultural Studies. He has supervised many theses and Doctorate } \\
\text { disertations. He has participated memerous national and international confrences and } \\
\text { has written a lot of articles. }\end{array}$ \\
\hline 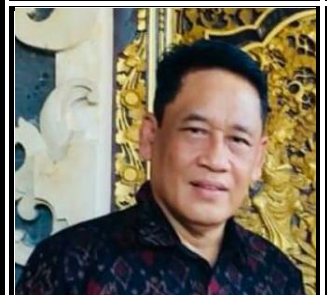 & $\begin{array}{l}\text { Prof. Dr. I Ketut Ardhana, M.A. Is a proffessor in Historical study Department at } \\
\text { Universitas Udayana, Denpasar, Indonesia. He received his Master in Southeast Asian } \\
\text { Studies from Australian National University. Australian in } 1994 \text { and hid Doctorate in } \\
\text { Philosophy from Passau University, Germany in } 2000 \text {. His research interest include a } \\
\text { wide range of topics related to Historical and Cultural Studies. He has supervised many } \\
\text { theses and doctorate dissertations. He has participated in several national and } \\
\text { international conferences and has written a lot of articles }\end{array}$ \\
\hline & \\
\hline & $\begin{array}{l}\text { Dr. I Ketut Setiawan, M. Hum. Is a Doctor in Cultural Studies and head of Archeologi } \\
\text { Departmen at Universitas Udayana, Denpasar, Indonesia. He received his Master in } \\
\text { Archeologi from Universitas Indonesia in } 1995 \text { and his Doctorate in Cultural Studies } \\
\text { from Universitas Udayana, Denpasar, Indonesia in } 2011 \text {. His research interest include a } \\
\text { wide range of topics related to Epigraphy, Culture, and tourism Studies. He has } \\
\text { supervised many theses and doctorate disertations. He has published many articles and } \\
\text { books and actively participated in national and international confrences and academic } \\
\text { workshops }\end{array}$ \\
\hline
\end{tabular}

